\title{
Keefektifan Model Quantum Teaching Berbantu Media Papan Flanel Laperdaman Terhadap Hasil Belajar IPA
}

\author{
Riski Septianingrum* \\ Pendidikan Guru Sekolah dasar (PGSD), FIP, Universitas PGRI Semarang
}

A R T I C L E I N F O

Article history:

Received 19 August 2018

Received in revised form

19 September 2018

Accepted 20 Oktober 2018

Available online 24

November 2018

\section{Kata Kunci:}

ModelQuantum Teaching

Media Papan Flanel, Hasil

Belajar

Keywords:

Quantum Teaching Model,

Flannel Board Media,

Learning.

\begin{abstract}
A B S T R A K
Latar belakang yang mendorong penelitian ini salah satunya adalah Guru mengajar secara konvensional tanpa menggunakan media karena terbatasnya fasilitas dari sekolah sehingga kurang membangunkan keantusiasan siswa dalam belajar IPA. Jenis Penelitian ini adalah penelitian kuantitatif. Desain yang digunakan dalam penelitian ini adalah Pre-Experimental Design dengan bentuk One Grup PretestPosttest Design. Populasi penelitian ini adalah seluruh siswa kelas $\mathrm{V}$ SDN 01 Rowoyoso tahun pelajaran 2018. Sampel yang diambil adalah satu kelas siswa dari kelas V SDN 01 Rowoyoso yang berjumlah 24 siswa dengan teknik Non Probability Sampling yang merupakan jenis sampling jenuh. Data dalam penelitian ini diperoleh melalui observasi, wawancara, tes dan dokumentasi. Berdasarkan hasil analisis data penelitian ini menunjukkan adanya perbedaan hasil pretest dan posttest. Rata-rata nilai pretest adalah 60,7 dan rata - rata nilai posttest adalah 83. Hal ini dibuktikan dengan perhitungan uji t- ketuntasan belajar yang diperoleh ttabel sebesar1,173 dan thitungsebesar 13,672.
\end{abstract} Jadi thitung > ttabelyang artinya siswa dapat mencapai kriteria ketuntasan yang telah ditetapkan. Persentase ketuntasan hasil belajar siswa mencapai 83\%. Dapat disimpulkan bahwa model Quantum Teaching berbantu media LAPERDAMAN efektif terhadap hasil belajar siswa materi sistem peredaran darah manusia kelas V SDN 01 Rowoyoso, Kecamatan Wonokerto, Kabupaten Pekalongan.

\section{A B S T R A C T}

The background that encourages this research is that one of the teachers teaches conventionally without using media because of the limited facilities from the school so that it does not awaken students' enthusiasm in learning science. This type of research is quantitative research. The design used in this study is Pre-Experimental Design with the form of One Pretest-Posttest Design Group. The population of this study were all fifth grade students of Rowoyoso Elementary School 01 2018 school year. The samples taken were one class of students from class V SDO 01 Rowoyoso which amounted to 24 students with Non Probability Sampling technique which is a type of saturated sampling. The data in this study were obtained through observation, interviews, tests and documentation. Based on the results of data analysis, this study shows the difference between pretest and posttest results. The average pretest score is 60.7 and the average posttest score is 83 . This is evidenced by the calculation of the learning completeness t-test obtained by t table of 1.173 and tcount of 13.672. So $t$ count $>t$ table which means students can achieve the predetermined completeness criteria. The percentage of completeness of student learning outcomes reached $83 \%$. It can be concluded that the Quantum Teaching model assisted by LAPERDAMAN media is effective on student learning outcomes in the human blood circulation system class V SDO 01 Rowoyoso, Wonokerto District, Pekalongan Regency.

Copyright (C) Universitas Pendidikan Ganesha. All rights reserved.

\footnotetext{
* Corresponding author.

E-mail addresses: riskiseptia58@gmail.com (Riski Septianingrum),
} 


\section{Pendahuluan}

Hakikat IPA itu memberikan pengertian bahwa IPA tidak hanya meliputi ilmu pengetahuan mengenai alam tetapi mencakup pengertian proses penyelidikan dan perolehan ilmu tersebut. Hakekat Ilmu Pengetahuan Alam adalah sebagai produk, proses dan sikap (Mulyasa 2009: 110). IPA sebagai produk merupakan akumulasi hasil upaya para perintis IPA terdahulu dan umumnya telah tersusun secara lengkap dan sistematis dalam bentuk buku teks. IPA yang dimaksud dengan proses di sini adalah proses mendapatkan IPA. IPA disusun dan diperoleh melalui metode ilmiah. Jadi yang dimaksud proses IPA adalah metode ilmiah. IPA sebagai pemupuk sikap adalah makna sikap pada pengajaran IPA dibatasi pengertiannya pada "sikap ilmiah terhadap alam sekitar" (Herlina, 2013). Pembelajaran IPA di sekolah dasar adalah memahami dengan baik materi IPA yang diajarkan, memahami dan memanfaatkan dengan baik cara siswa belajar IPA secara efektif, menggunakan cara-cara pembelajaran IPA serta memahami dan menerapkan cara memanfaatkan media sebagai alat bantu belajar IPA.

Berdasarkan hasil wawancara yang dilakukan di SDN 01 Rowoyoso Kecamatan Wonokerto Kabupaten Pekalongan khususnya di kelas V terdapat kurang dari $50 \%$ jumlah siswa yang mengalami kesulitan berhitung pada mata pelajaran IPA dengan materi sistem peredaran darah pada manusia. Hasil belajar siswa yang rendah dapat dilihat pada hasil tes IPA masih banyak siswa yang mendapat nilai kurang dari KKM yaitu 70. Hal ini disebabkan karena adanya kesulitan dalam memahami materi sistem peredaran darah manusia. Penyebab kesulitan tersebut adalah : 1) Guru mengajar secara konvensional tanpa menggunakan media karena terbatasnya fasilitas dari sekolah sehingga kurang membangunkan keantusiasan siswa dalam belajar IPA, 2) Kurangnya penggunaan model pembelajaran yang dapat menumbuhkan aktivitas dan kreativitas siswa dalam pembelajaran, 3) Lemahnya siswa dalam memahami materi sistem peredaran darah manusia.

Hal tersebut menjadikan nilai belajar IPA saat UTS siswa kelas V SDN 01 Rowoyoso sebagian besar masih rendah, dapat dilihat dari Tabel dibawah ini:

Tabel 1. Data Hasil Ulangan Tengah Semester Gasal Tahun 2017/2018 di Kelas V SDN 01 Rowoyoso

\begin{tabular}{|c|c|c|c|c|c|c|}
\hline \multirow{2}{*}{$\begin{array}{l}\text { Jumlah } \\
\text { siswa }\end{array}$} & \multirow[t]{2}{*}{ KKM } & \multirow{2}{*}{$\begin{array}{l}\text { Rata-rata } \\
\text { Kelas }\end{array}$} & \multicolumn{2}{|c|}{ Tuntas } & \multicolumn{2}{|c|}{ Tidak Tuntas } \\
\hline & & & Jumlah & $(\%)$ & Jumlah & $(\%)$ \\
\hline 24 & 7,0 & 63,5 & 11 & $45,8 \%$ & 13 & $54,1(\%)$ \\
\hline
\end{tabular}

Pemanfaatan model pembelajaran yang baik dalam proses pembelajaran inilah yang sangat berperan penting bagi guru dan siswa. Quantum Teaching adalah penggubahan belajar yang meriah, dengan segala nuansanya Bobbi DePorter (2006). Quantum Teaching ini juga menyertakan segalakaitan, interaksi, dan perbedaan yang memaksimalkan momen belajar. Quantum Teaching berfokus pada hubungan dinamis dalam lingkungan kelas interaksi yang mendirikan landasan dan kerangka untuk belajar. pendapat tersebut didukung pula oleh penelitian Susiani dkk (2013), dalam jurnal pendidikan dasar yang menyimpulkan bahwa pembelajaran model quantum teaching dapat meningkatkan kecerdasan sosio-emosional dan meningkatkan prestasi belajar siswa Model ini mempunyai kerangka kegiatan berupa TANDUR (Tumbuhkan, Alami, Namai, Demontrasi, Ulangi, dan Rayakan) yang pembelajarannya mengharuskan siswa untuk aktif dalam pembelajaran. Selain itu hasil penelitian yang dilakukan oleh Kian, Dumanauw, dan Tengko yang menyatakan bahwa terdapat perbedaan yang nyata antara haisl belajar siswa pada materi Pemuaian Zat yang diberi penerapan model pembelajaran Quantum Teaching dengan hasil belajar siswa yang tidak diberi penerapan model pembelajaran Quantum Teaching.

\section{Metode}

Metode yang digunakan dalam penelitian ini adalah metode kuantitatif. Menurut Sugiyono (2015: 8) menyatakan bahwa metode penelitian kuantitatif dapat diartikan sebagai metode penelitian yang berlandaskan pada filsafat positivisme, digunakan untuk meneliti pada populasi atau sampel tertentu, pengumpulan data menggunakan instrumen penelitian, analisis data bersifat kuantitatif/statistik, dengan tujuan untuk menguji hipotesis yang telah ditetapkan.

Desain penelitian adalah pola yang menggambarkan bagaimana peneliti melakukakan analisis terhadap fakta atau data yang dikumpulkan.Dalam penelitian ini, peneliti menggunakan desain PreExperimental Design (nondesigns) dengan jenis One-Group Pretest-Posttest Design.Pada desain ini terdapat 
pretest, sebelum diberi perlakuan.Dengan demikian hasil perlakuan dapat diketahui lebih akurat, karena dapat membandingkan dengan keadaan sebelum diberi perlakuan. Desain ini dapat digambarkan seperti berikut :

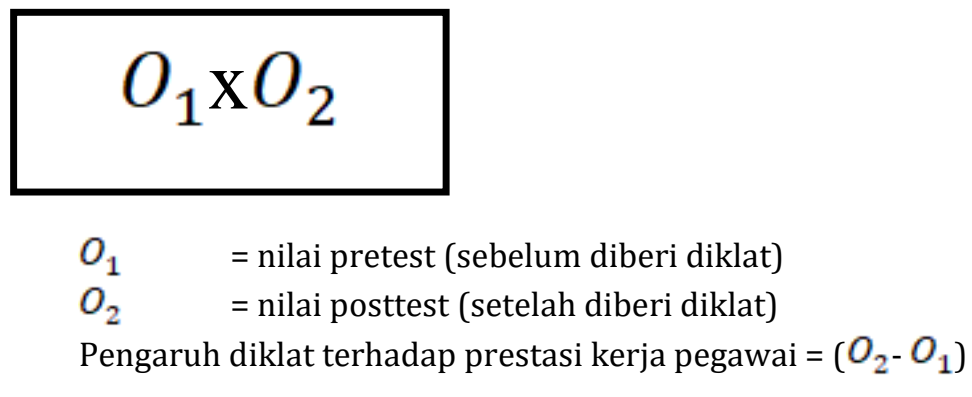

\section{Hasil dan pembahasan}

(Sugiyono, $2015: 75$ ).

Data hasil penelitian diperoleh dari nilai pretest dan posttest hasil belajar siswa.Nilai pretest dan posttest dinyatakan tuntas jika memenuhi KKM. Adapun Kriteria Ketuntasan Minimal (KKM) mata pelajaran IPA SDN 01 RowoyosoKecamatan Wonokerto Kabupaten Pekalongan yaitu 67.Perhitungan nilai pretest dan posttest setelah diberikan perlakuan hasilnya berbeda.

Berikut tabel nilai pretest dan posttestsiswa kelas V SDN 01 Rowoyoso tahun ajaran 2018/2019 dapat dilihat pada Tabel 2 data Hasil belajar pretest dan posttestberikut :

Tabel 2. Nilai pretest dan posttest

\begin{tabular}{lll}
\hline Keterangan & Pretest & Posttest \\
\hline Nilai Tertinggi & 92 & 100 \\
Nilai Terendah & 36 & 66 \\
Rata-rata & 60,667 & 83,333 \\
Selisih rata-rata pretest dan posttest & \multicolumn{2}{c}{22,667} \\
\hline \multicolumn{2}{c}{ Sumber : Data Hasil Peneltian (2018) }
\end{tabular}

Berdasarkan tabel 2 terdapat perbedaan antara nilai terendah, nilai tertinggi dan nilai rata-rata kelas pada saat pretest dan posttest.Nilai pretest diperoleh nilai terendah 36 dan nilai tertinggi 92 sedangkan posttest diperoleh nilai terendah 66dan nilai tertinggi 100. Nilai rata-rata pretest atau sebelum diberi perlakuan sebesar 60,666setelah diberi perlakuan dengan menggunakan model pembelajaran Quantum Teaching dengan media LAPERDAMAN (lalulintas peredaran darah manusia) nilai rata-rata posttest siswa yaitu 83,333. Dari data nilai pretest dan posttest tersebut dapat digambarkan dalam diagaram 1 Hasil pretest dan posttestsebagai berikut :

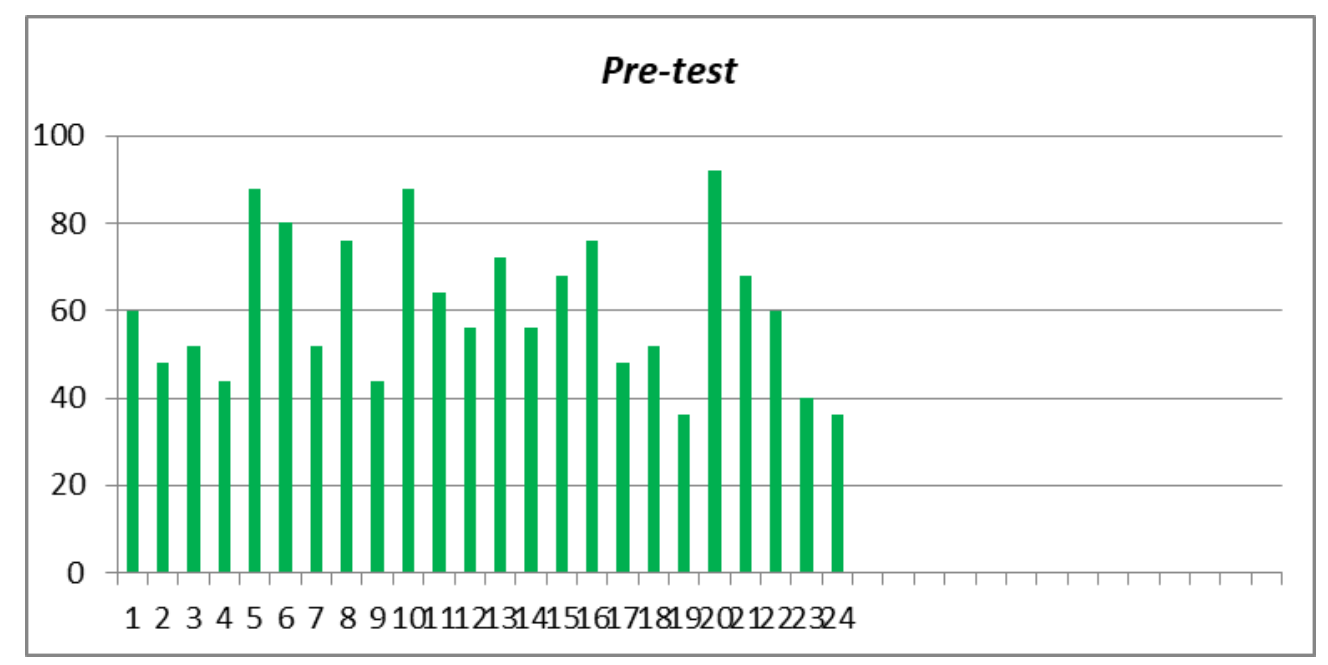

Gambar 1. Diagram Distribusi Nilai Pre-test 
Berdasarkan pada gambar 1 diatas yang diagramnya berwarna hijau adalah menunjukkan tingkat nilai siswa saat pretest dilakukan sebelum pembelajaran dengan menggunakan model quantum teaching yang berbantu media LAPERDAMAN. Dapat dilihat ada beberapa siswa yang tuntas dalam mengerjakan soal pretest tersebut.

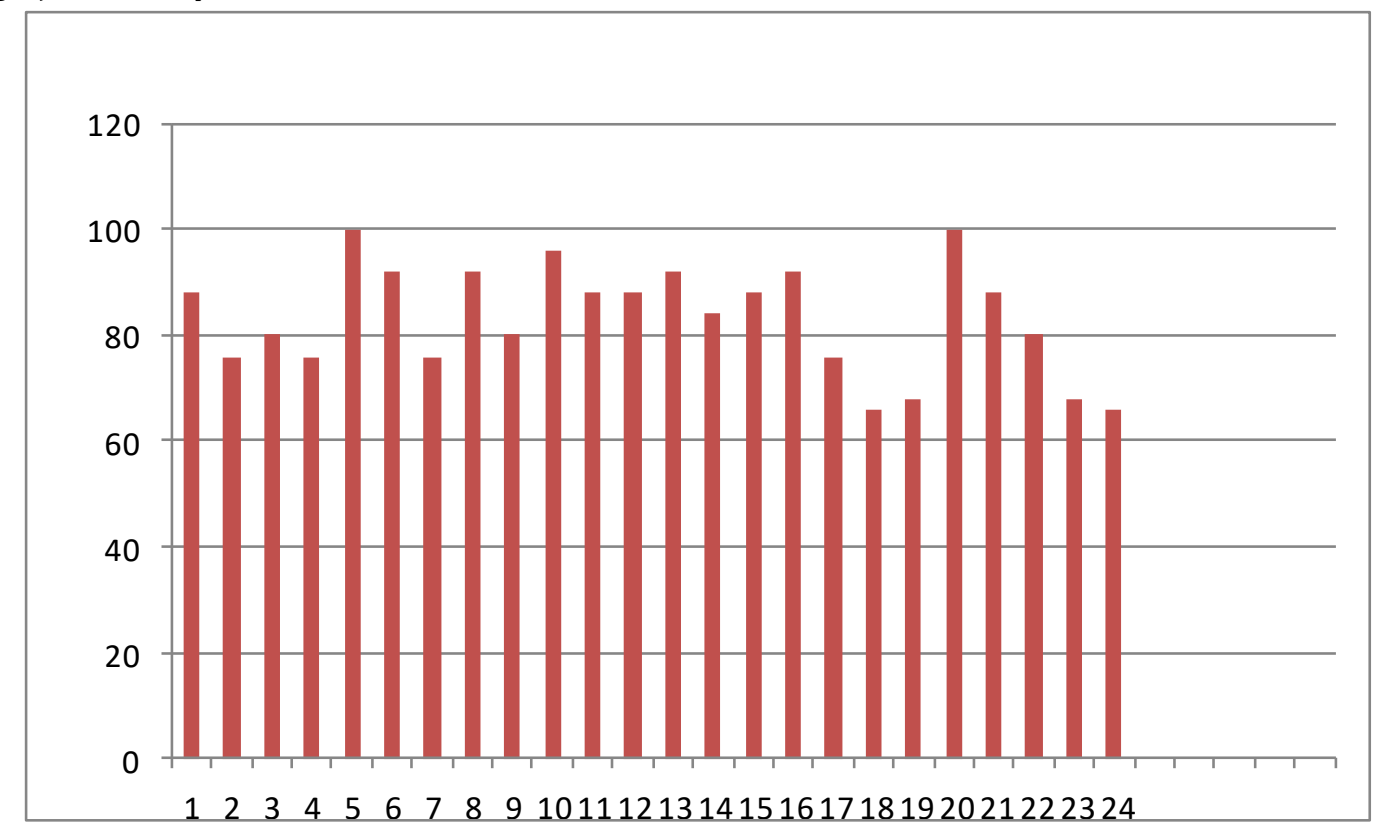

Gambar 2. Diagram Distribusi Nilai Posttest

Berdasarkan gambar 2 menunjukkan nilai posttest yang dapat dilihat bahwa ada peningkatan dengan nilai posttest dibandingkan dengan nilai pretest. Ada peningkataan pada nilai posttest siswa setelah menerapkan pembelajaran yang menggunakan model yang belum pernah diterapkan yaitu model pembelajaran quantum teaching

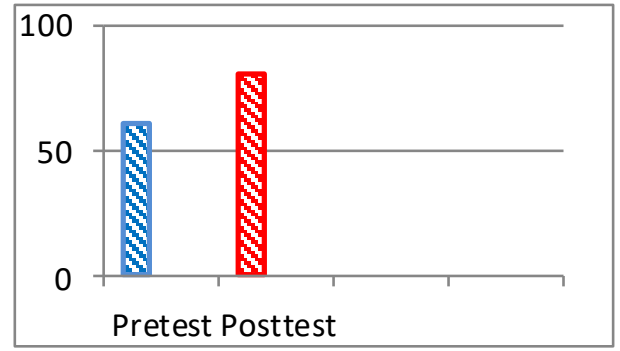

Gambar 3. Diagram Hasilpretest dan posttest

Berdasarkan Diagram 3 hasil pretest dan posttest menunjukkan bahwa terdapat peningkatan antara pretest yang sebelum diberikan perlakuan dengan nilai posttest yang sudah diberikan perlakuan dengan model pembelajaran Quantum Teaching dengan media LAPERDAMAN (lalulintas peredaran darah manusia).

Uji prasyaratan analisis data pada penelitian harus dilakukan sebelum menguji hipotesis sehingga dapat diambil suatu kesimpulan dari penelitian yang telah dilakukan.Uji prasyaratan penelitian ini terdiri dari analisis awal dan analisis akhir.Analisis awal meliputi analisis instrumentuji coba dan uji normalitas.Analisis data akhir meliputi uji normalitas dan uji t.

\section{Analisis Awal (Uji Normalitas pretest)}

Perhitungan yang digunakan untuk mengetahui normalitas data awal sampel menggunakan uji Liliefors, pada taraf signifikan 5\%. Kriteria dalam uji normalitas ini adalah :

$L_{0}<L_{\text {tabel }}$ maka populasi berdistribusi normal

$L_{0} \geq L_{\text {tabel }}$ maka populasi tidak berdistribusi normal 
Tabel 3. Hasil Uji Normalitas Awal

\begin{tabular}{lllll}
\hline Kelas & $\mathrm{N}$ & $L_{0}$ & $L_{\text {tabel }}$ & Kesimpulan \\
\hline Responden & 24 & 0,098567 & 0,176 & Berdistribusi Normal \\
& & & & Sumber : Data Hasil Penelitian (2018)
\end{tabular}

Berdasarakan tabel 3 Hasil uji normalitas awal diperoleh harga mutlak selisih yang paling besar $L_{0}=0,098567$ dengan $\mathrm{n}=24$ dan taraf nyata $\alpha=5 \%$ dari daftar nilai kritis $\mathrm{L}$ di dapat $L_{\text {tabel }}=0,176 \mathrm{karena}$ $L_{0}<L_{\text {tabel }}$ yaitu $0,098567<0,176$ maka $H_{0}$ diterima. Hasil uji normalitas menunjukkan bahwa data pretest siswa berasal dari populasi yang berdistribusi normal.

\section{Analisis Akhir (Uji Normalitas Posttest)}

Perhitungan yang digunakan untuk mengetahui normalitas data akhir sampel menggunakan uji Liliefors.Pada taraf signifikan 5\% .

Kriteria dalam uji normalitas ini adalah :

$L_{0}<L_{\text {tabel }}$ maka populasi berdistribusi normal

$L_{0} \geq L_{\text {tabel }}$ maka populasi tidak berdistribusi normal

Tabel 4. Hasil Uji Normalitas Awal

\begin{tabular}{lllll}
\hline Kelas & $\mathrm{N}$ & $L_{0}$ & $L_{\text {tabel }}$ & Kesimpulan \\
\hline Responden & 24 & 0,115 & 0,176 & $\begin{array}{l}\text { Berdistribusi } \\
\text { Normal }\end{array}$ \\
\hline & & & Sumber : Data Hasil Penelitian (2018)
\end{tabular}

Berdasarakan tabel 4 Hasil uji normalitas akhir diperoleh harga mutlak selisih yang paling besar $L_{0}=0,115$ dengan $\mathrm{n}=24$ dan taraf nyata $\alpha=5 \%$ dari daftar nilai kritis $\mathrm{L}$ di dapat $L_{\text {tabel }}=0,176 \mathrm{karena}$ $L_{0}<L_{\text {tabel }}$ yaitu $0,115<0,176$ maka $H_{0}$ diterima. Hasil uji normalitas menunjukkan bahwa data pretest siswa berasal dari populasi yang berdistribusi normal.

Pengujian hipotesis menggunakan uji t. Untuk mengetahui ada atau tidak perbedaan hasil belajar antara peserta didik yang mendapatkan perlakuan dengan peserta didik yang tidak mendapatkan perlakuan, digunakan uji t. Pengujian dua sampel pada prinsipnya dilakukan untuk menguji perbedaan rata-rata nilai pretest dan posttest. Hipotesis yang akan diuji adalah sebagai berikut :

Diterima Ho jika $t_{\text {hitung }}<t_{\text {tabel }}$ ( hal ini berarti tidak ada perbedaan yang signifikan antara hasil belajar pretest dan posttest ). Ditolak Ho jika $t_{\text {hitung }}>t_{\text {tabel }}$ (hal ini berarti ada perbedaan signifikan antara hasil belajar pretest dan posttest).Untuk mengetahui adakah perbedaan hasil belajar siswa, maka digunakan uji t. Adapun rumus uji t yang digunakan adalah :

$$
\begin{array}{ll}
\mathrm{t}=\frac{M d}{\sqrt{\left(\frac{\sum x^{2} d}{N(N-1)}\right.}} & \\
\text { keterangan : } & =\text { harga } \mathrm{t} \\
\mathrm{t} & =\text { mean dari perbedaan pretest dengan posttest. } \\
\mathrm{Md} & =\text { jumlah kuadrad deviasi } \\
\sum \mathrm{x} 2 \mathrm{~d} & =\text { subjek pada sampel. } \\
\mathrm{N} &
\end{array}
$$

\begin{tabular}{|c|c|c|c|c|c|}
\hline Subjek & Hasil Belajar & Rata-rata & $\mathrm{N}$ & $t_{\text {hitung }}$ & $t_{\text {tabel }}$ \\
\hline \multirow[t]{2}{*}{ Kelas V SDN 01 Rowoyoso } & Pretest & $\begin{array}{l}60,66667 \\
83,33333\end{array}$ & 24 & 13,672 & 1,173 \\
\hline & Posttest & & & & \\
\hline
\end{tabular}

Berdasarkan perhitungan uji t diperoleh data sebagai berikut :

Tabel 5. Hasil perhitungan uji t Hasil Belajar 
Berdasarkan tabel 5 diperoleh harga $t_{\text {hitung }}=13,672$. Selanjutnya harga $t_{\text {hitung }}$ tersebut dibandingkan dengan $t_{\text {tabel }}=1,173$ pada taraf signifikan $\alpha=5 \%$ sehingga diperoleh harga $t_{\text {hitung }}>t_{\text {tabel }}$ yait $u 13,672>1,173$. Dengan demikian $H_{0}$ ditolak dan $H_{a}$ diterima.

Dapat disimpulkan bahwa terdapat perbedaan nilai pretest dan posttest hasil Belajar Matematika siswa kelas V SDN 01 Rowoyoso Kecamatan Wonokerto Kabupaten Pekalongan.

Penelitian ini dilakukan pada semester ganjil bulan Juli 2018 di SDN 01 RowoyosoKecamatan Wonokerto Kabupaten Pekalongan tahun pelajaran 2018/2019 pada siswa kelas V dengan jumlah 24 siswa. Sebelum melaksanakan penelitian, peneliti melaksanakan studi pendahuluan untuk mengetahui permasalahan yang ada di kelas dan diperoleh informasi bahwa dalam proses pembelajaran IPA di kelas guru sudah menggunakan metode pembelajaran tetapi belum menggunakan metode pembelajaran yang menarik. Selain itu, penggunaan media dalam pembelajaran juga masih kurang, guru tidak selalu menggunakan media dalam setiap pembelajaran, sehingga pembelajaran yang dilakukan terkesan monoton dan membuat siswa cepat merasa bosan. Akibat muncul karena permasalahan tersebut terlihat pada hasil pretest yang memiliki nilai rata-rata rendah dan belum mencapai Kriteria Ketuntasan Minimal (KKM) yang sudah ditentukan yaitu 70. Dari jumlah 24 siswa diperoleh data bahwa tidak ada yang memiliki nilai tuntas.

Peneliti mempersiapkan rencana pelaksanaan pembelajaran yang akan dilaksanakan dalam 2 kali pertemuan. Dalam pelaksanaan pembelajaran pertemuan pertama menggunakan model quantum teaching dan media LAPERDAMAN (lalulintas peredaran darah manusia) dengan materi sistem peredaran darah manusia, pertemuan ke 2 mengggunakan model quantum teaching dengan materi penyakit peredaran darah manusia dan penyebabnya. Sebelum menerapkan pembelajaran menggunakan model pembelajaran quantum teaching dengan media LAPERDAMAN (lalulintas peredaran darah manusia), peneliti terlebih dahulu membagikan soal pilihan ganda sebagai pretest kepada siswa untuk dikerjakan pada pertemuan pertama.

Penggunaan model model pembelajaran Quantum Teaching yang dilakukan peneliti yaitu dengan carasiswa ditempatkan dalam kelompok-kelompok. Setiap kelompok terdiri dari 4-5 anggota/siswa. Guru memberikan soal untuk dikerjakan secara kelompok dan maju mengambil soal yang terdapat pada media pembelajaran lalu mempraktekannya menggunakan media tersebut. Siswa yang menjawab dan mempraktekkannya dengan benar mendapat reward.

Dengan demikian dapat menumbuhkan semangat siswa dalam mengikuti pembelajaran serta hasil belajar siswa meningkat. Sebelum siswa menerapkan model quantum teaching, peneliti dalam menerapkan model tersebut dengan berjalan secara spontan dan menggunakan media peniliti mengajarkan terlebih dahulu dan siswa akan memahami apa yang harus dilakukan serta memahami materi yang akan disampaikan. Karena pada akhir pembelajaran siswa akan diberikan soal posttest sebagai alat evaluasi sehingga akan diketahui apakah model pembelajaran quantum teaching akan meningkatkan hasil belajar IPA pada siswa kelas V di SDN 01 Rowoyoso Kecamatan Wonokerto Kabupaten Pekalongan.

Data penelitian ini terdiri data pretest dan posttest Pre-experimen design. Berikut adalah daftar nilai pretestdan posttest SD Negeri 01 Rowoyoso yang disajikan dalam bentuk Tabel:

\section{Hasil Pretest dan Postest}

Tabel 6. Hasil nilai Pretest dan Postest

\begin{tabular}{lll}
\hline Keterangan & Pretest & Posttest \\
\hline Nilai tertinggi & $\underline{92}$ & 100 \\
Nilai terendah & 36 & 66 \\
Rata-rata & 60,67 & 83,33 \\
\hline
\end{tabular}

Sumber data: Data Hasil Penelitian 2018

Berdasakan Tabel 6 diatas dapat dilihat bahwaada perbedaan yang terdapat pada nilai siswa yaitu pretest dan postest. Nilai pretest siswa yang tertinggi adalah 92 dan terendah adalah 36 dan nilai postest tertinggi adalah 100 dan terendah adalah 66 terdapat selisih masing-masing rata-rata adalah 60,67 pada pretest dan 83,33 pada posttest. Hal tersebut menunjukkan bahwa ada peningkatan dari nilai pretest dan posttest yang sebelum diberikan perlakuan dengan menggunakan model quantum teaching dengan berbantu media papan flanel LAPERDAMAN. 


\section{Uji Normalitas \\ Uji Normalitas Awal}

Tabel 7. Hasil Uji Normalitas Lilifors Awal

\begin{tabular}{lll}
\hline$L_{\text {hitung }}$ & $L_{\text {tabel }}$ & Keterangan \\
\hline 0,115167 & 0,176 & Normal \\
\hline & & Sumber Data: Data Hasil Penelitian 2018
\end{tabular}

Berdasarkan Tabel 7 menunjukkan bahwa data uji normalitas awal berdistribusi normal dengan

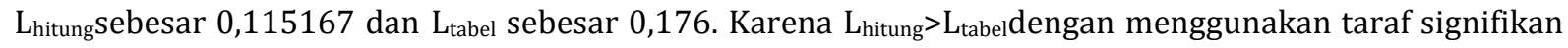
sebesar $5 \%$.

\section{Uji normalitas data akhir}

Tabel 8. Hasil Uji Normalitas Lilifors Akhir

\begin{tabular}{lcc}
\hline$L_{\text {hitung }}$ & $L_{\text {tabel }}$ & Keterangan \\
\hline 0,098567 & 0,176 & Normal \\
\hline
\end{tabular}

Berdasarkan Tabel 8 terlihat bahwa $\mathrm{L}_{\text {hitung }}<\mathrm{L}$ tabel $0,098567<0,176$ pada taraf signifikan $5 \%$ dengan $\mathrm{N}=24$ sehingga $\mathrm{H}_{0}$ diterima. Dengan demikian nilai posttest berasal dari populasi.

\section{Uji Hipotesis uji t}

Data yang didapat dalam penelitian, selanjutnya dianalisis dengan uji-t, uji ini dilakukan untuk mengetahui dan memeriksa efektifitas perlakuan.Pembuktian signifikan perbedaan penggunaan model lama dan baru perlu diuji secara statistik menggunakan desain one group pre-test post-test design.

Sebelum menentukan signifikan atau tidaknya data tersebut, maka terlebih dahulu merumuskan hipotesis aternatif $(\mathrm{H} \alpha)$ dan hipotesis nihil $\left(\mathrm{H}_{0}\right)$ sebagai berikut:

HO : $\mu 1=\mu 2$ (Tidak ada perbedaan hasil belajar pretest dan posttest siswa dengan pembelajaran model quantum teaching berbantu media laperdaman).

$\mathrm{H} \alpha: \mu 1 \neq \mu 2$ (Ada perbedaan hasil belajar pretest dan posttest siswa dengan pembelajaran model quantum teachingberbantu media laperdaman).

Kriteria:

Diterima Ho jika $t_{\text {hitung }}<t_{\text {tabel }}$ ( hal ini berarti tidak ada perbedaan yang signifikan antara hasil belajar pretest dan posttest ). Ditolak Ho jika $t_{\text {hitung }}>t_{\text {tabel }}$ (hal ini berarti ada perbedaan signifikan antara hasil belajar pretest dan posttest). ttabel diperoleh dengan derajat kebebasan untuk ditribusi $t$ ialah (N-1) dan taraf signifikan 5\%.

Rumus yang digunakan yaitu.

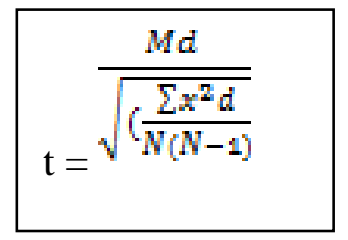

(Arikunto, 2010: 306-307)

Setelah melakukan tes dari soal instrumen penelitian perhitungannya dapat dilihat pada lampiran, diperoleh $\mathrm{Md}=23$ dan $\sum x^{2} \mathrm{~d}=1462.00$ dan $\mathrm{N}(\mathrm{N}-1)=552$. Sehingga diperoleh $\mathrm{t}_{\text {tabel }}=1,173$ dan $\mathrm{t}_{\text {hitung }}$ $=13,672$. Karena $t_{\text {hitung }}>t_{\text {tabel }}$ yaitu $13,672>1,173$, maka $\mathrm{H}_{0}$ ditolak. 


\section{Uji Ketuntasan belajar Klasikal}

Tabel 9. Hasil Ketuntasan Hasil Belajar Pretest dan Posttest

\begin{tabular}{lll}
\hline Kriteria & Pretest & Posttest \\
\hline Tuntas & $30 \%$ & $83 \%$ \\
Tidak Tuntas & $70 \%$ & $17 \%$ \\
\hline
\end{tabular}

Sumber: Data Hasil Penelitian 2018

Hasil perhitungan ketuntasan belajar klasikal dapat dilihat pada lampiran. Presentase KBK pretest adalah 30\% dan posttest 83\%. Dapat dilihat bahwa terjadi peningkatan presentase 53\%.

Berdasarkan perhitungan nilai pretest yang dilakukan diperoleh kesimpulan bahwa kelas $\mathrm{V}$ di SDN 01 Rowoyoso Kecamatan Wonokerto Kabupaten Pekalongan berdistribusi normal karena nilai $L_{0}<L_{\text {tabel }}$ yaitu $0,098567<0,176$ dengan $\mathrm{n}=24$ dan taraf nyata $\alpha=0,05$. Pada tahap akhir berikutnya dilakukan kembali uji normalitas dengan menggunakan nilai posttest. Berdasarakan perhitungan diperoleh $t_{\text {hitung }}>t_{\text {tabel }}$ yaitu $13,672>1,173$, maka $H_{0}$ ditolak sehingga dapat disimpulkan bahwa sampel berasal dari populasi berdistribusi normal. Selanjutnya perhitungan uji t hasil belajar siswa menunjukkan bahwa diketahui $t_{\text {hitung }}$ lebih besar dari $t_{\text {tabel }}(10,83>1,729)$ maka $H_{0}$ ditolak. Jadi dapat disimpulkan bahwa $H_{a}$ diterima, artinya nilai postest siswa setelah menggunakan model pembelajaran Quantum Teaching ada perbedaan signifikan sebelum dan sesudah menggunakan model. Hasil penelitian ini jga didukung oleh penelitian Arpan (2016) yang menunjukkan terdapat peningkatan hasil belajar siswa menggunakan model Quantum Teaching pada materi Perangkat Keras Komputer dengan thitung $>$ ttabel $(20,69>2,04)$. Sugandika (2013) yang menunjukkan bahwa hasil penelitian ini menunjukkan bahwa terdapat perbedaan pemahaman konsep IPA yang signifikan antara siswa yang mengikuti pembelajaran dengan model pembelajaran quantum teaching dan siswa yang mengikuti pembelajaran dengan model pembelajaran konvensional kelas IV di Gugus VII Kecamatan Buleleng tahun pelajaran 2012/2013. Hasil Penelitian oleh Dewi (2013) menunjukkan bahwa penerapan model pembelajaran quantum teaching dapat meningkatkan hasil belajar siswa.

Hal ini dikarenakan sudah diterapkan pembelajaran menggunakan model pembelajaran Quantum Teaching dengan media LAPERDAMAN (lalulintas peredaran darah manusia). Berdasarkan hasil di atas, dapat disimpulkan bahwa model pembelajaran Quantum Teaching dengan media LAPERDAMAN (lalulintas peredaran darah manusia) dapat meningkatkan hasil belajar IPA dengan materi sistem peredaran darah manusia siswa kelas V SDN 01 Rowoyoso Kecamatan Wonokerto Kabupaten Pekalongan.

\section{Simpulan dan saran}

Pada hasil uji ketuntasan belajar menunjukkan bahwa hasil belajar siswa kelas V SDN 01 Rowoyosoyang menggunakan model pembelajaran Quantum Teaching dengan media LAPERDAMAN (lalulintas peredaran darah manusia)bilangan mencapai KKM 70. Nilai rata-rata pretest60,66667dan Kriteria Ketuntasan Minimal (KKM) 70, diperoleh t_hitung = 13,672 dengan n = 24 dan $t_{-}($tabel ) $=1,173$, sehingga hasil perhitungan diketahui t_hitung>t_tabel, dapat disimpulkan bahwa hasil belajar materi sistem peredaran darah manusia mencapai KKM 70.

Adapun saran dari kegiatan ini adalah penggunaan model Quantum Teaching terhadap hasil belajar siswa materi sistem peredaran darah manusia pelajaran IPA siswa kelas V SDN 01 Rowoyoso dapa dijadikan alternatif pembelajaran.

\section{Daftar Rujukan}

Arikunto, Suharsimi. 2010. Prosedur Penelitian. Jakarta: Rineka Cipta.

Arpan, Muhamad, Sahbidin. 2016. Efektivitas Model Pembelajaran Quantum Teaching Dalam Peningkatan Hasil Belajar Teknologi Informasi Dan Komunikasi . Jurnal Edukasi, Vol. 14, No. 2.

DePorter, B, dkk. (2010). QuantumTeaching. Bandung: KAIFA.

Dewi, Luh Putu Purnama. 2018. Penerapan Model Pembelajaran Quantum Teaching berbantuan Media Konkret untuk Meningkatkan Hasil Belajar IPA. Journal of Education Action Research Volume 2, Number 1 
Feladi, V. \& Marlianto, F. 2015. “Penerapan Model Pembelajaran Quantum Teaching untuk Meningkatkan Hasil Belajar Mahasiswa dalam Materi Pembuatan Database dan Tabel Menggunakan SQL". Jurnal Pendidikan Informatika dan Sains Vol. 4 No. 1 (2015). Pontianak: IKIP PGRI Pontianak.

Herlina W., L. PT. , Nym. Dantes, Wyn. Suwatra. 2013. Pengaruh Model Pembelajaran Quantum Teaching Terhadap Minat Dan Hasil Belajar Ipa Siswa Kelas Iv Gugus Xiii Kecamatan Buleleng. Jurnal Jurusan PGSD Universitas Pendidikan Ganesha Volume 1 Nomor 1.

Kian, Z., Dumanauw, M. L., \& Tengko, S. 2013. "Peningkatan Hasil Belajar Siswa dengan Model Pembelajaran Quantum Teaching di SMP Negeri 3 Tondano”. JSME MIPA UNIMA Vol. 1, No. 1 (2013): Fisika. Manado: Universitas Negeri Manado.

Mulyasa. 2009. Kurikulum Tingkat Satuan Pendidikan. Bandung: PT Remaja Rosdakarya.

Samatowa,Usman. 2010, Pembelajaran IPA di Sekolah Dasar. Jakarta: Indeks.

Sugandika, I Gd Kawit, Ni Ngh Madri Antari, I Gd Margunayasa. 2013. Pengaruh Model Quantum Teaching Terhadap Pemahaman Konsep Ipa Siswa Kelas Iv Di Gugus Vii Kecamatan Buleleng. Mimbar PGSD UNdiksha Vol 1 No 1.

Sugiyono. 2015. Metode Penetitian Pendidikan. Bandung: Alfabeta.

Susiani, K dkk. (2013). Pengaruh Model Pembelajaran Quantum Terhadap Kecerdasan Sosio-Emosional dan Prestasi Belajar IPA Siswa Kelas V SD Bayuning. Jurnal Penelitian Pendidikan Dasar (online). Vol. 03.

Widiyaningsih, E.dan Pujiastuti, E.2013. Keefektifan Pembelajaran Model Quantum Teaching Berbantuan Cabri 3D Terhadap Kemampuan Pemecahan Masalah. JURNAL KREANO, Volume 4 Nomor 1.

Yahya, Husniyati. 2017. Pengaruh Penerapan Model Pembelajaran Quantum Teaching Terhadap Hasil Belajar Biologi Siswa Sms Islam Terpadu Al-Fityan Gowa . Jurnal Biotek Volume 5 Nomor 1 